\title{
ASPEK HUKUM PELAKSANAAN KEWENANGAN BIDAN DALAM PELAYANAN KEBIDANAN \\ ${ }^{1}$ Indrie Lutfiana, ${ }^{2}$ Ni Ketut Ayu Wulandari \\ 1 email : abdullah08112011@ gmail.com \\ STIKES BULELENG
}

\begin{abstract}
ABSTRAK
Pemerintah bersama masyarakat bertanggung jawab untuk menjamin bahwa setiap ibu memiliki akses terhadap pelayanan kesehatan ibu yang berkualitas. Tujuan penelitian ini adalah untuk kajian pelaksanaan kewenangan dan kompetensi bidan dalam memenuhi standar pelayanan kesehatan khususnya dalam bidang pelayanan kebidanan di Kabupaten Buleleng.

Tujuan penelitian ini yaitu untuk mengetahui aspek hukum pelaksanaan kewenangan bidan dalam pelayanan kebidanan. Desain penelitian ini desain penelitian kualitatif dengan studi deskriptif fenomenologi. Sampel dalam penelitian ini sebanyak 25 responden.

Dari hasil penelitian dapat diketahui dasar hukum dalam pelaksanaan kewenangan dan kompetensi bidan dalam memenuhi standar pelayanan kebidanan meliputi UU Kesehatan Nomor 36 Tahun 2009, UU Pemerintah Daerah Nomor 23 tahun 2014, UU No 12 Tahun 2012 Tentang Pendidikan Tinggi, Kepmenkes 369 Tentang Standar Profesi Bidan Tahun 2007, Peraturan Menteri Riset, Teknologi Dan Pendidikan Tinggi Ri Nomor 44 Tahun 2015 Tentang Standar Nasional Pendidikan Tinggi dan Permenkes No 28 Tahun 2017 Tentang Izin Dan Penyelenggaraan Praktik Bidan.

Pelaksanaan kewenangan oleh bidan yang berkerja kurang dari 3 tahun sesuai dengan kewenangan bidan 38 kewenangan (100 \%) dan BPM memberikan kewenangan 23 kewenangan $(60,5 \%)$ dari 38 kewenangan.
\end{abstract}

Kata Kunci : Aspek Hukum, Kewenangan,Kebidanan 


\section{LEGAL ASPECT FOR THE IMPLEMENTATION OF THE AUTHORITY OF MIDWIVES IN MIDWIFERY SERVICES}

The government and the community are responsible for ensuring that every mother has access to quality maternal health services. The purpose of this study was to study the implementation of the authority and competence of midwives in meeting health service standards, especially in the midwifery service sector in Buleleng Regency.

The purpose of this study was to determine the legal aspects of implementing the authority of midwives in midwifery services. This research design is a qualitative research design with a phenomenological descriptive study. The sample in this study were 25 respondents.

From the research results, it can be seen that the legal basis for implementing the authority and competence of midwives in meeting midwifery service standards includes Health Law Number 36 of 2009, Regional Government Law Number 23 of 2014, Law Number 12 of 2012 concerning Higher Education, Kepmenkes 369 concerning Professional Standards of Midwives. 2007, Regulation of the Minister of Research, Technology and Higher Education RI Number 44 of 2015 concerning National Standards for Higher Education and Permenkes No. 28 of 2017 concerning Licensing and Implementation of Midwife Practices.

The exercise of authority by midwives who have worked less than 3 years in accordance with the authority of midwives 38 authorities (100\%) and BPM provides 23 authorities $(60.5 \%)$ of 38 authorities

Key Word : legal aspect, authority, midwifery

\section{PENDAHULUAN}

Pembangunan kesehatan pada dan pemberdayaan masyarakat bersamahakekatnya diarahkan guna tercapainya sama dengan tenaga kesehatan lainnya kesadaran, kemauan dan kemampuan untuk senantiasa siap melayani siapa saja hidup sehat bagi setiap orang, yang membutuhkannya, kapan dan menyangkut fisik, mental, maupun sosial dimanapun dia berada. Survei budaya dan ekonomi ${ }^{1}$. Bidan merupakan pendahuluan yang dilakukan di salah salah satu tenaga kesehatan yang satu Bidan Praktik Mandiri didapatkan memiliki posisi penting dan strategis data bahwa ada bidan praktik yang terutama dalam penurunan Angka diduga melakukan praktik kebidanan Kematian Ibu (AKI) dan angka kesakitan tidak sesuai dengan kewenangan dan kematian Bayi (AKB). Bidan sehingga menyebabkan terjadinya memberikan pelayanan kebidanan yang kematian pada ibu hamil. Pertolongan berkesinambungan dan paripurna, persalinan dilakukan oleh bidan yang berfokus pada aspek pencegahan, masih magang, sehingga bidan tersebut promosi dengan berlandaskan kemitraan menyalahi aturan karena melimpahkan

1'https://www.poltekkesjakarta1.ac.id/read-gk-eppelayanan-kebidanan-dan-ruang- lingkupnya,pelayanan kebidanan dan ruang lingkupnya, 15 Juli 2017 
kewenangan pada calon bidan yang disebabkan ketidak inginan pasangan belum memiliki sertifikasi kompetensi. suami istri untuk ber $\mathrm{KB}$, cakupan $\mathrm{KB}$ Pelayanan kebidanan merupakan bagian sebesar $77.8 \%$, ini berarti cakupan KB yang tidak terpisahkan dari sistem belum mencapai target yang diharapkan pelayanan kesehatan. Pelayanan yaitu $80 \%$. Cakupan penangan kebidanan merupakan layanan yang komplikasi resiko tinggi sebesar $65.8 \%$ diberikan oleh bidan sesuai kewenangan yang seharusnya capaian targetnya bidan yang diarahkan untuk adalah $100 \%$. Dan cakupan pemberian mewujudkan kesejahteraan keluarga tablet $\mathrm{Fe}$ sebesar $92.95 \%$ yang terutama ibu dan anak sehingga terwujud seharusnya adalah $100 \%{ }^{3}$. Dengan data keluarga bahagia, sejahtera dan diatas menunjukkan adanya pelayanan berkualitas $^{2}$. Pada Peraturan Menteri kebidanan yang tidak optimal sehingga Kesehatan Nomor 43 Tahun 2016 angka kematian maternal di Kabupaten Tentang Standar Pelayanan Minimal Buleleng masih tinggi, oleh sebab itu Bidang Kesehatan, kewenangan bidan pelayanan kebidanan perlu mendapatkan tidak hanya terkait dengan pertolongan perhatian yang serius dari pemerintah.

asuhan kebidanan fisiologis tetapi 2. METODE PENELITIAN

kewenangan bidan juga mencakup 1) Desain Penelitian

asuhan kebidanan dengan komplikasi. Jenis penelitian ini adalah desain Kewenangan normal merupakan penelitian kualitatif dengan studi kewenangan yang dimiliki oleh setiap deskriptif dengan metode survey. Desain bidan. Kewenangan bidan untuk ini digunakan karena melihat masih menjalankan program pemerintah adanya perbedaan pelaksanaan merupakan kewenangan khusus bagi kewenangan bidan dalam memberikan bidan yang bekerja untuk pemerintah pelayanan kebidanan sesuai dengan dalam mensukseskan program masa kerja bidan.

pemerintah. Sedangkan kewenangan bidan yang tidak memiliki dokter pada daerah tertentu merupakan kewenangan pelimpahan bagi bidan namun kewenangan tersebut akan dicabut apabila di daerah tersebut sudah terdapat dokter. Bidan dalam menjalankan tugasnya harus memiliki pendidikan yang formal, mempunyai sistem pelayanan, kode etik dan etika kebidanan dalam melaksanakan tugas dan tanggung jawabnya secara professional, dalam hal ini tercantum pada Peraturan Menteri Kesehatan No 28 Tahun 2017 Tentang Izin Dan Penyelenggaraan Praktik Bidan. Buleleng memiliki cakupan K4 $94.7 \%$ yang belum mencapai target yang diharapkan yaitu $95 \%$. Angka kematian yang tinggi dapat dipengaruhi juga oleh angka kelahiran yang tinggi yang

\section{2) Waktu dan Lokasi Penelitian}

Penelitian ini dilakukan pada Bulan Juni 2019 sampai dengan Desember 2019

dan dilakukan di Wilyah Kabupten Buleleng.

3) Variabel yang Diukur

Variabel penelitian ini adalah aspek hukum kewenangan bidan dalam memberikn pelayanan kebidanan.

\section{4) Teknik Sampling}

Penelitian ini menggunakan teknik purposive sampling (berdasarkan ciri kelompoknya) berdasarkan kriteria inklusi. Adapun subjek penelitian ini adaalh bidan yang ada di Wilayah Kabupaten Buleleng. Narasumber dalam penelitian ini diantaranya Ketua IBI PC Buleleng.

\section{5) Alat/Instrumen Penelitian}

Teknik pengumpulan data dilakuakn dengan metode wawancara dan studi kepustakaan. Data yang didapat

3 Internet, Profil Dinas Kesehatan Kabupaten Buleleng, 2014,http/www.dinkes.baliprov.go.id 
kemudian akan dianalisis menggunakan analisis data kualitatif.

\section{6) Analisis Data}

- Penelitian ini menggunakan analisis data kualitiatif dengan menggunakan software SPSS.

\section{HASIL DAN PEMBAHASAN}

\section{Hasil Penelitian}

\section{A. Pengaturan Kewenangan}

1) Undang-Undang No 36 tahun 2009 Tentang Kesehatan.

Peyelenggaraan praktik kebidanan memiliki payung hukum yaitu berdasarkan Undang-Undang No 36 tahun 2009 Tentang Kesehatan. Dalam peraturan tersebut bidan merupakan bidang profesi yang harus menjalankan pelayanan kesehatan sesuai dengan kewenangannya. berdasarkan Pasal 23 ayat (1) Undang-Undang No 36 tahun 2009 Tentang Kesehatan mengatur"Tenagakesehatanberwenang untuk menyelenggarakan pelayanan kesehatan. Izin untuk menyelenggarakanpelayanankesehatan diatur pada Pasal 23 ayat (3) "Dalam menyelenggarakan pelayanan kesehatan, tenaga kesehatan wajib memiliki izin dari pemerintah". Sesuai dengan peraturan tersebut, Pasal 23 Ayat (5), " Ketentuan mengenai perizinan sebagaimana dimaksud pada ayat (3) diatur dalam peraturan menteri. Penyelenggaraan izin praktik bidan diatur pada Peraturan Menteri Kesehatan Republik Nomor 28 Tahun 2017 tentang Izin dan Penyelenggaran Praktik Bidan.

2) Undang-Undang Nomor 36 Tahun 2014 tentang Tenaga Kesehatan Undang-Undang Nomor 36 Tahun 2014 tentang Tenaga Kesehatan bertujuan agar Tenaga kesehatan dalam menjalankan tugasnya harus bertanggungjawab, memiliki etika dan moral yang tinggi, keahlian dan kewenangan yang secara terus menerus ditingkatkan.

Tenaga kesehatan dalam menjalankan praktik berdasarkan kewenangan seperti yang disebutkan dalam Pasal 62 ayat (1) undangundang tenaga kesehatan yaitu “" Tenaga kesehatan dalam menjalankan praktik harus dilakukan sesuai dengan kewenangannya yang didasarkan pada kompetensi yang dimilikinya". Kewenangan yang dimaksud berdasarkan kompetensi dijelaskan adalah kewenangan untuk melakukan pelayanan secara mandiri sesuai dengan keahlian dan kompetensinya.

3) Peraturan Menteri Kesehatan Nomor 28 tahun 2017 tentang Izin dan Penyelenggaraan Praktik Bidan.

Pelimpahan wewenang bidan diatur pada Peraturan Menteri Kesehatan Nomor 28 tahun 2017 tentang Izin dan PenyelenggaraaN Praktik Bidan, Pelimpahan Wewenang tindakan pelayanan kesehatan oleh bidan diatur pada Pasal 22 butir (b) yaitu pelimpahan wewenang yang dilakukan bidan dalam melakukan tindakan pelayanan kesehatan diberikan secara mandat dari dokter, pelayanan kesehatan yang diberikan secara mandat oleh dokter kepada bidan akan menjadi tanggung jawab dokter sebagai pemberi mandat.

Penyelenggaraan praktik bidan sebelumnya diatur dalam Keputusan Menteri Kesehatan No 900 Tahun 2002 Tentang Registrasi Dan Praktik Bidan. Pasal 14 menyebutkan kewenangan bidan meliputi pelayanan kebidanan, pelayanan keluarga berencana dan pelayanan keseahatan masyarakat. Dalam Keputusan tersebut seorang bidan dalam melaksanakan pelayanan kesehatan dapat melakukan kewenangan normal maupun abnormal berdasarkan 
B. Pengaturan Kewenangan Bidan Pasal 21 Permenkes No 28 Tahun 2017 dalam memenuhi Standar Pelayanan Kebidanan

Tentang Izin Dan Penyelenggaraan

Praktik Bidan mengatur secara tegas

Pasal 11 dalam UU RI Nomor 36 bahwa kewenangan bidan dalam Tahun 2014 Tentang Tenaga Kesehatan kesehatan reproduksi perempuan dan menegaskan bidan adalah salah satu keluarga berencana terbatas dalam tenaga kesehatan, dimana tenaga penyuluhan \& konseling kesehatan kesehatan didalam menjalankan reroduksi dan pelayanan kontrasepsi kewenangannya harus sesuai dengan oral, kondom dan suntikan, Sedangkan peraturan yang berlaku di Indonesia. UU dalam Kepmenkes 369 Tentang Standar NO 36 Tahun 2009 Tentang Kesehatan Profesi Bidan Tahun 2007 mengatur Pasal 23 menyebutkan bahwa "Tenaga bahwa kompetensi bidan yang kedua kesehatan berwenang untuk adalah Bidan memberikan asuhan yang menyelenggarakan pelayanan kesehatan bermutu tinggi, pendidikan kesehatan " dan dalam hal ini Kewenangan bidan yang tanggap terhadap budaya dan diatur dalam Permenkes No 28 Tahun pelayanan menyeluruh dimasyarakat 2017 Tentang Izin Dan Penyelenggaraan dalam rangka untuk meningkatkan Praktik Bidan, kewenangan yang kehidupan keluarga yang sehat, dimiliki bidan dalam memberikan perencanaan kehamilan dan kesiapan pelayanan kesehatan terdiri dari menjadi orang tua.

pelayanan kesehatan ibu, pelayanan dilaksanakan oleh pemerintah pusat atau kesehatan anak dan pelayanan kesehatan peerintah daerah bersama dengan reproduksi perempuan dan keluarga organisasi profesi.

berencana. Seorang bidan dalam Selanjutnya Kewenangan bidan menjalankan kewenangan harus sesuai sesuai dengan Peraturan izin dengan standar profesi, memiliki penyelenggaraan bidan adalah keterampilan dan kemampuan untuk kesehatan reproduksi dan keluarga melakukan tindakan yang dilakukan dan berencara. Pada peraturan tersebut mengutamakan kesehatan ibu dan bayi kewenangan bidan adalah penyuluhan atau janin. dan konseling kesehatan reproduksi

Kewenangan yang tercantum perempuan dan keluarga berencana dalam Permenkes No 28 Tahun 2017 sedangkan pada standar pelayanan Tentang Izin Dan Penyelenggaraan kebidanan kesehatan reproduksi adalah Praktik Bidan memberikan bidan dalam deteksi dini kanker melalui memberikan pelayanan kesehatan ibu pemeriksaan IVA khusus mulai usia hamil, ibu bersalin, ibu nifas, anak 30-59 tahun.

balita dari konseling sampai dengan

penanganan kegawatdaruratan

selanjutnya diikuti dengan rujukan.

C. Pelaksanaan Kewenangan

Tabel Distribusi bidan melakukan

kewenangan bidan di tempat kerja 
2. Pembahasan

A. Pengaturan Kewenangan

\begin{tabular}{|c|c|c|c|}
\hline $\begin{array}{l}\mathrm{N} \\
\mathrm{O}\end{array}$ & Tempat & $\begin{array}{l}\text { Bekerja } \\
<3 \text { tahun }\end{array}$ & $\begin{array}{c}\text { Bekerja } \\
\geq 3 \text { tahun }\end{array}$ \\
\hline 1 & $\begin{array}{l}\text { BPM } \\
\text { Kubutamba } \\
\text { han }\end{array}$ & $\begin{array}{c}25 \\
\text { kewenang } \\
\text { an }\end{array}$ & $\begin{array}{c}38 \\
\text { kewenan } \\
\text { gan }\end{array}$ \\
\hline 2 & $\begin{array}{l}\text { BPM } \\
\text { Sangsit }\end{array}$ & $\begin{array}{c}31 \\
\text { kewenang } \\
\text { an }\end{array}$ & $\begin{array}{c}38 \\
\text { kewenan } \\
\text { gan }\end{array}$ \\
\hline 3 & $\begin{array}{l}\text { BPM } \\
\text { Sawan I }\end{array}$ & $\begin{array}{c}31 \\
\text { kewenang } \\
\text { an }\end{array}$ & $\begin{array}{c}38 \\
\text { kewenan } \\
\text { gan }\end{array}$ \\
\hline 4 & $\begin{array}{l}\text { BPM } \\
\text { Sawan II }\end{array}$ & $\begin{array}{c}23 \\
\text { Kewenan } \\
\text { gan }\end{array}$ & $\begin{array}{c}38 \\
\text { kewenan } \\
\text { gan }\end{array}$ \\
\hline
\end{tabular}

1) Undang-Undang RI Nomor 36

Tahun 2009 Tentang

Kesehatan

Undang-Undang RI Nomor 36 Tahun 2009 Tentang Kesehatan ini mengandung asas keadilan yang tertuang pada Pasal 23 ayat (1) yang sesuai dengan teori yang dikemukakan menurut aristoteles tentang keadilan berbasis persamaan. Dalam Pasal ini tertuang jelas kesamaan derajat setiap orang dalam hukum dalam memberikan pelayanan kesehatan. Sesuai dengan UndangUndang Nomor 12 Tahun 2011 Tentang Pembentukan peraturan Perundang-Undangan, UndangUndang RI Nomor 36 Tahun 2009 Tentang Kesehatan lebih tinggi dari pada peraturan menteri kesehatan, jadi sesuai dengan ketentuan tersebut Undang-Undang RI Nomor 36 Tahun 2009 Tentang Kesehatan berhak mengamanatkan peraturan yang lebih rendah dan ini sesuai dengan pernyataan pada Undang-Undang RI Nomor 36 Tahun 2009 Tentang Kesehatan Pasal 23 ayat (3) yang mengamanatkan tentang izin penyelenggaraan

pelayanan

kesehatan.

2) Undang-Undang RI Nomor 36 Tahun 2014 Tentang Tenaga Kesehatan

Bidan dalam melaksanakan pelayanan kesehatan tidak hanya melakukan pelayanan sesuai kewenangan mandiri tetapi dapat melaksanakan pelayanan kesehatan diluar kewenangan bidan. UndangUndang Nomor 36 Tahun 2014 tentang Tenaga Kesehatan Pasal 65 ayat (1) mengatur tenaga kesehatan dapat menerima pelimpahan tindakan medis dari tenaga medis. Yang dikelompokkan tenaga medis dalam Undang-Undang Nomor 36 Tahun 2014 tentang Tenaga Kesehatan adalah Dokter, dokter gigi, dokter spesialis dan dokter spesialis gigi. Dari Pasal 65 ayat (1) tersebut bidan dapat menerima pelimpahan tindakan medis dari tenaga medis dan yang bertanggung jawab jika terjadi kelalaian atau kesalahan dalam tindakan medis adalah yang memberikan mandat.

3) Peraturan Menteri Kesehatan

Nomor 28 tahun 2017 tentang

Izin dan Penyelenggaraan

Praktik Bidan.

Kewenangan bidan berdasarkan Peraturan Menteri Kesehatan Republik Indonesia Nomor 28 tahun 2017 tentang Izin dan Penyelenggaraan Praktik Bidan terdiri dari pelayanan kesehatan ibu, pelayanan kesehatan anak, pelayanan kesehatan reproduksi dan keluarga berencana.
B. Pengaturan Kewenangan Bidan dalam memenuhi Standar Pelayanan Kebidanan
1) Undang-Undang Nomor 23 Tahun $2014 \quad$ Tentang Pemerintah Daerah.


Dalam amanat mendasar Undangundang 1945 adalah upaya pembangunan nasional yaitu pembangunan dalam segala aspek guna kepentingan, keselamatan, kebahagian dan kebahagian seluruh rakyat Indonesia secara terarah, terpadu dan berkesinambungan. Pembangunan kesehatan ditingkatkan melalui upaya promotof, preventis, kuratif dan kuratif yang dilaksanakan oleh seluruh lapisan masyarakat khususnya tenaga kesehatan melalui pelayanan kesehatan yang bermutu dan berkualitas, salah satu pelayanan kesehatan adalah pelayanan kebidanan "Pelayanan kebidanan merupakan bagian integral dari pelayanan kesehatan yang diarahkan untuk mewujudkan kesehatan keluarga dalam rangka tercapainya keluarga yang berkualitas" . Pelayanan kebidanan terdiri dari pelayanan primer, pelayanan sekunder dan pelayanan tersier.

2) Peraturan Pemerintah No 2 Tahun 2018 Tentang Standar Pelayanan Minimal

Peraturan Menteri Kesehatan Nomor 43 Tahun 2016 Tentang Standar Pelayanan Minimal Bidang Kesehatan sudah sesuai dengan peraturan pemerintah, yang terdiri dari pelayanan kesehatan ibu, bayi baru lahir,balita dan pelayanan usia reproduktif.

\section{Pelaksanaan Kewenangan}

BPM Sangsit dan BPM Kubutambahan hanya memberikan 31 kewenangan dari 38 kewenangan. Kewenangan yang tidak diberikan oleh kepala BPM Sangsit Dan Kubutambahan adalah kewenangan yang kepala bidan anggap beresiko menyebabkan kesakitan atau kematian pada ibu dan bayi. Sehingga bidan tidak dapat memberikan secara penuh kewenangan tersebut. Kepala
BPM Sawan I dan Sawan II masingmasing hanya memberikan 23 dan 25 kewenangan dari 38 kewenangan. Dari pernyataan bidan mengatakan kewenangan yang diberikan hanya 23 dan 25 kewenangan tetapi kewenangan yang lainnya diberikan dengan pengawasan. Sesuai dengan peraturan Menteri Kesehatan Nomor 28 tahun 2017 tentang Izin dan Penyelenggaraan Praktik Bidan, bidan yang sudah lulus dan mendapkan sertifikat kompetensi seharusnya sudah dapat menjalankan kewenangannya. Dan bidan sudah dianggap cakap dalam menjalankan pelayanan kebidanan sesuai kewenangannya.

\section{KESIMPULAN}

A. Undang-Undang No 36 tahun 2009 Tentang Kesehatan Pasal 23 Ayat 1 bahwa tenaga kesehatan berwenang melakukan pelayanan Kesehatan dan Pasal 23 Ayat (5) penyelenggaraan pelayanan kesehatan harus mendapatkan izin dari pemerintah.

B. Undang-Undang Nomor 36 Tahun 2014 tentang Tenaga Kesehatan 62 ayat (1) dalam menjalankan praktik harus sesuai dengan kewenangan dan kompetensinya dan Pasal 65 ayat (1) dalam melakukan pelayanan kesehatan, tenaga kesehatan dapat menerima pelimpahan dari tenaga medis lainnya.

C. Peraturan Menteri Kesehatan Nomor 28 tahun 2017 tentang Izin dan Penyelenggaraan Praktik Bidan Pasal 18, bidan dalam memiliki kewenanganpelayanan kesehatan ibu, pelayanan kesehatan anak dan pelayanan kesehatan reproduksi \&keluarga berencana. 
D. PelaksanaanPemberiankewenang an bidan sesuai dengan hasil penelitian mencapai $100 \%$ pada bidan yang bekerja lebih dari tiga tahun dan bagi bidan yang bekerja sebelum tiga tahun hanya diberikan kewenangan 60,5\%. Darihasil yang didapatkan,

E. Pelaksanaan Standar Pelayanan Kebidanan oleh 30 bidan yang bekerja diatas tiga tahun mencapai $100 \%$ dan dari 30 bidan yang bekerja dibawah tiga tahun sebagian besar pelaksanaannya 90 $\%$ dan ada duabidan yang melaksanakan pelayanan kebidanan sebanyak $50 \%$.

\section{REFERENSI}

Dinas Kesehatan Kabupaten Buleleng, 2016, Profil Kesehatan Kabupaten Buleleng Tahun 2016, Buleleng : Dinas Kesehatan Kabupaten Buleleng

Hasibuan, Malayu S.P. 2009. Manajemen (Dasar, Pengertian dan Masalah). Bumi Aksara. Jakarta

Iqbal Wahid \& Nurul chayatin, 2009, Ilmu Kesehatan Masyarakat (teori dan aplikasi), Jakarta : Salemba Medika

J. Guwandi, 1996, Dokter Pasien dan Hukum, Jakarta: Fakultas Kedokteran Universitas Indonesia

Lexy Moleong, 2014, Metode Penelitian Kualitatif, Bandung : PT Remaja Rosdakarya

Lutfi Effendi, 2003, Pokok-Pokok Hukum Administrasi, Malang : Bayumedia Publishing
Mufdhilah, dkk, 2012, Konsep

Kebidanan, Yogjakarta : Muha Medika

Najih Mokhammad, 2016, Pengantar Hukum Indonesia, Malang : Setara Press

Oka Mahendra, Pedoman Praktis Legal Drafting, 2017, Malang

Prof dr Ida Bagus Gede Manuaba,1998,Ilmu Kebidanan, Penyakit Kandungan Dan Keluarga Berencana Untuk Pendidikan Bidan, Jakarta : EGC

Prajudi Atmosudirdjo, 1981, Hukum Administrasi Negara, Ghalia Indonesia, Jakarta

Roni Hanitijo Soemitro, 1988, Metodologi Penelitian Hukum dan Jurimetri, Jakarta:GhaliaIndonesia

Sugiyono, 2011, Metode Penelitian Kuntitatif Kualitatif dan R\&D,Bandung : Alfabeta 